\title{
The Reproductive Aspect of Tropical Abalone (Haliotis asinina L.) in the Waters of Tanakeke Islands at South Sulawesi
}

\author{
Hadijah (Corresponding author) \\ Fishery Departement, Faculty of Agriculture, University 45 of Makassar Indonesia \\ Indonesia \\ Ambo Tuwo \\ Fishery Departement, Faculty of Agriculture, University 45 of Makassar Indonesia \\ Indonesia
}

Magdalena Litaay

Faculty of Fishery and Marine Science, Hasanuddin University of Makassar Indonesia Indonesia

Erni Indrawati

Fishery Departement, Faculty of Agriculture, University 45 of Makassar Indonesia Indonesia

Received: February 28, 2013 Accepted: April 3, 2013 Published: July 1, 2013

doi:10.5296/ast.v1i2.3721 URL: http://dx.doi.org/10.5296/ast.v1i2.3721

\begin{abstract}
The objective of research was to analyze the reproductive aspect of abalone (Haliotis asinina L.) which included the beginning of gonad maturity, the peak of spawning season, the comparison of male and female abalone caught in the nature, the reproductive potential, and abalone fecundity. Research was located at the waters of Tanakeke Islands, Takalar District, South Sulawesi. Method of research was field survey. Sampling stations were determined
\end{abstract}




\section{Macrothink

based on the distribution of coral reef in the islands. Result of research indicated that male abalone reached the beginning of gonad maturity at shell length of $64.50 \mathrm{~mm}$, while female abalone reached it at shell length of $64.09 \mathrm{~mm}$. Abalone had spawned throughout year with two peaks of spawning season, precisely at the beginning of dry season and rainy season. The comparison of male and female abalone primes was 1:1. Abalone group with shell length of $60-70 \mathrm{~mm}$ contributed more than $70 \%$ to the total reproductive potential of the population. Total fecundity of the tropical abalone at research was ranging from 255,900 to 756,200 eggs.

Keywords: Tropical Abalone (Haliotis asinina L.), Gonad maturity, Reproductive potential, fecucndity 


\section{Introduction}

Abalone (Haliotis asinina) is a mollusk species that belonged to gastropode/snail class. It was identified by its shape of ear, and thus, it was called as 'donkey ear'. This abalone was a popular export commodity. It was favorite food among people in other countries such as Japan, United States, Europe Countries, Columbia and Canada. Because its delicious meat. Indeed, 100 grams abalone meat contained 83 calories, $59 \mathrm{mg}$ cholesterol, $0.1 \mathrm{~g}$ lipid, $2.7 \mathrm{~g}$ carbohydrate, and vitamins B1, B2, B6 and B12, as well as some minerals such as calcium, iron, zinc, magnesium and selenium.

Market demand was high, and therefore, abalone was continually exploited and subjected to the reduction of population (Maliao et al., 2004). The preservation of abalone resources must need management actions, including the management of hauling, the closure of hauling region and season, the limitation of work quantity and hauling outcome, or the prevail of quota system (Rounsefell, 1975, Gulland, 1977). However, cultivation was a solution that was recently coming into consideration.

Abalone cultivation was always possible if the seed was available in constant. To obtain the seed in constant, thus, seeding was needed. However, a main problem in abalone seeding was lack of availability of local prime. A location that was expected to become the producer of local abalone prime was Tanakeke Islands, an island cluster in the Spermonde Islands. Tanakeke was, in fact, abalone hauling site. Coral reefs were surrounding the island (Yunus, 2009).

One of the problems in the abalone hatchery has been the availability of a local broodstock. Therefore, information about the existence and potential of the local broodstock that can be as the source of the broodstock for purposes of abalone hatchery in South Sulawesi. Review on the reproductive biological aspect, thus, should be very important.

\section{Research Method}

Research method was survey. It was located abalone catch at region around the waters of Tanakeke Islands, Mangarabombang Subdistrict, Takalar District. The coordinate of this site was $05^{\circ} 29^{\prime} 10.9^{\prime}$ 'South Latitude and $119^{\circ} 18$ ' 54.6" East Longitude. Sample was collected for one year starting from April 2008 to March 2009. Reproductive biological parameters were measured at Fishery Biology Laboratory, Faculty of Marine and Fishery Sciences, University of Hasanuddin. Histology preparation was conducted at Laboratory of Sea Animal Physiological Ecotoxicology and Laboratory of Fish Parasite and Disease of Faculty of Marine and Fishery Sciences, University of Hasanuddin; and Laboratory of Fish Rehabilitation, University of Hasanuddin, Makassar. Parameters that were observed were: (a) sex ratio, (b) gonad macroscopic character, (c) gonad microscopic character, (d) gonad maturity rate, (e) gonad maturity index, (f) the beginning of gonad maturity, (g) reproductive potential, and (h) abalone fecundity. 


\section{Macrothink}

\section{Result and Discussion}

\subsection{Sex Ratio}

Sex ratio was calculated based on the comparison of male and female samples in every month. The comparison of sex ratio between male and female was shown in Figure 1.

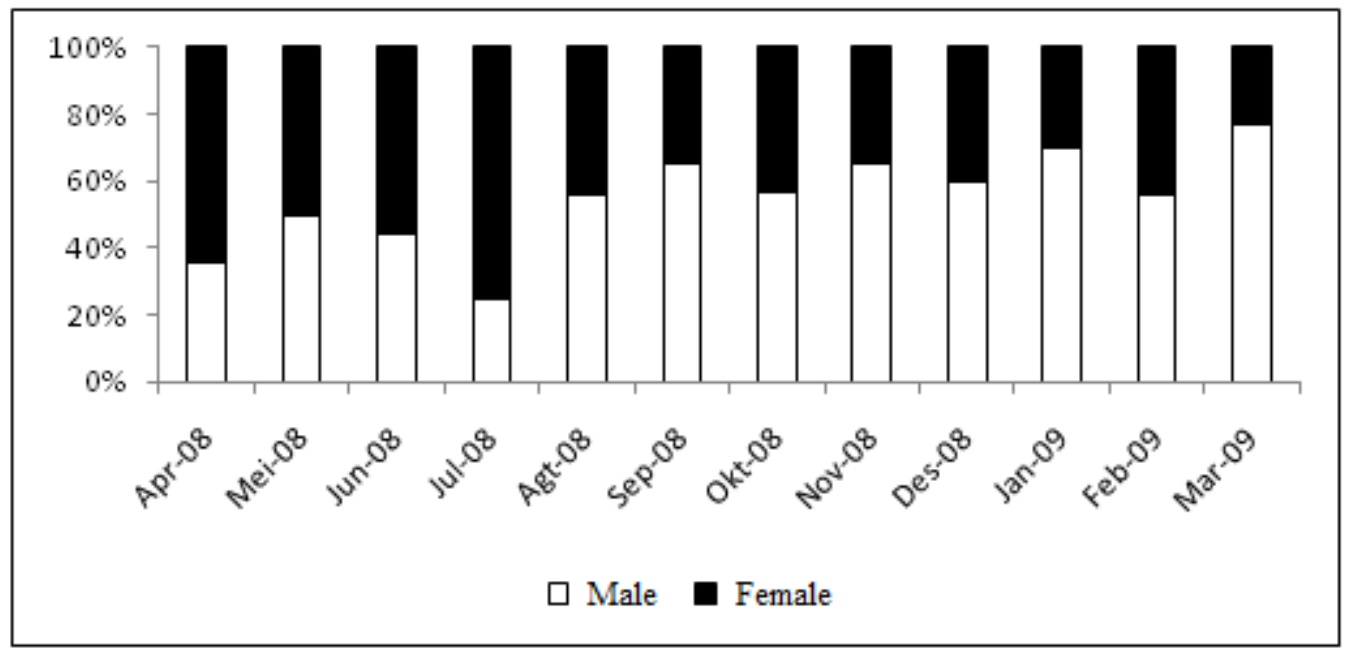

Figure 1. The comparison between male and female Haliotis asinina abalones In Tanakeke Islands

Figure 1 showed the comparison of sex ratio of male and female abalones, that was 167: 129 or 1.29: 1.00. Some similar results had been given by Fleming and Hone (1996). Who reported that tropical abalone, Haliotis asinine, in Thailand and Philippine had sex ratio of male and female of 1:1. Capinpin, et al. (1998); Setyono (2006) found that sex ratio of male and female Haliotis asinina abalones in the waters of South Lombok, Nusa Tenggara Barat, at young population (shell length of $<50 \mathrm{~mm}$ ) was not obviously different from 1:1, but at adult population (shell length $>50 \mathrm{~mm}$ ), it seemed that number of female was greater than male. The different sex ratio between young and adult populations was estimated as being affected by the difference of individual mortality rate of male and female (Campbell et al., 2003).

\subsection{The Beginning of Gonad Maturity}

Result of research indicated that male abalone reached the beginning of gonad maturity at shell length of $64.50 \mathrm{~mm}$ (Figure 2), while female abalone was at $64.09 \mathrm{~mm}$ (Figure 3). Other abalone species, such as Haliotis discus hannai that was reared in hatchery, had its gonad matured at shell length of $30 \mathrm{~mm}$ (Awaji dan Hamano, 2004). The abalone that was catched in sub-tropical region was different in the beginning of gonad maturity. $H$. rufescens in California reached the beginning of gonad maturity at shell length of $150 \mathrm{~mm}$, while $H$. cracherodii reached it at shell length of $140 \mathrm{~mm}$ (Del Proo, 1992) and H. kamtschatkana at Canada reached it at shell length of $44 \mathrm{~mm}$ (McShane,1992). 


\section{Mll Macrothink}

The difference of the size of the beginning of gonad maturity of abalone was influenced by some factors such as temperature of waters, habitat condition and catching pressure (Hahn, 1989b; Capinpin et al., 1998; Counihan et al., 2001; Malioao et al., 2004). Waters temperature had influenced the assembly of central nerve, but it was then influencing hormone System, especially related to reproductive hormone (Grubert dan Ritar, 2005) Temperature might also influence metabolism of the body if the food was adequate in the nature. Some proportions of unused energy in the body, therefore, were used for gonad development.

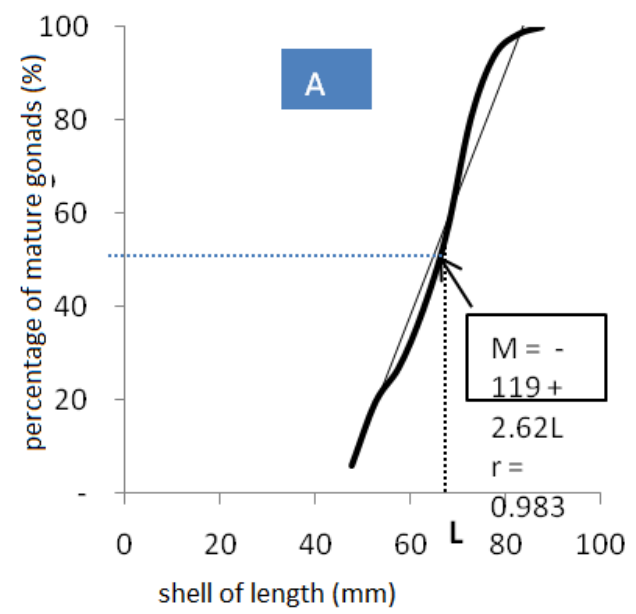

Figure 2. The percentage of gonad matured individual of male abalone that were counted based on gonad matured individual (TKG 3, 4 and 5)

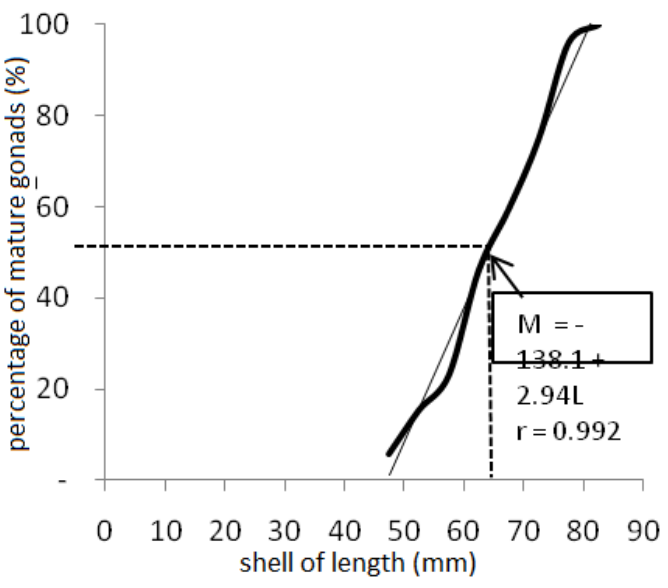

Figure 3. The percentage of gonad matured individual of female abalone that was counted based on gonad matured individual (TKG 3, 4 and 5)

\subsection{Macroscopic and Microscopic Characters of Gonad}

Macroscopically, abalone gonad was positioned in the right section across the hollowed part of shell. Female gonad was bluish green, while male gonad was whitish cream. The observations of microscopic character of abalone gonad by Nash (1992) had showed that $\mathrm{H}$. asinina gonad that was not yet developed (immature or TKG 0) was causing difficulty in identifying gonad between ovary and testis. In this phase, gonad was characterized by the absence of or the presence of few germinal epithelium in the gonad tissue, precisely between outer membrane of gonad (outer epidermis) and digestive gland.

In the proliferated phase (TKG 1), gonad was distinguished between testis containing sperm core (spermatogonia) and ovary containing egg core (previtellogenic oocytes). Gonad had entered maturity (maturing or TKG 2) if there was a thin layer of spermatid and/or spermatozoa in the testis at diameter between 50-125 $\mu \mathrm{m}$. The matured testis (ripe or TKG 3) was solid due to the content of spermatozoa, while the matured ovary seemed solid with the ripe egg within it, and dominated by the egg with diameter more than $120 \mu \mathrm{m}$. Meanwhile, 


\section{$\triangle$ Macrothink}

the partially spawned testis (TKG 4) was indicated by the hollow space in some sperm pouches (tubules), while the other tubules were solid due to the content of spermatozoa. The partially spawned ovary was signed by empty gonad tissue (gonad lumen), while the remaining was still solid with the ripe egg.

The totally spent gonad (TKG 5) was observed by the empty gonad with no more matured gamete (spermatozoa and oocytes) left. Gonad lumen was destroyed, while trabeculae and tubules were shrunk and folded (Figure 3 and 4).

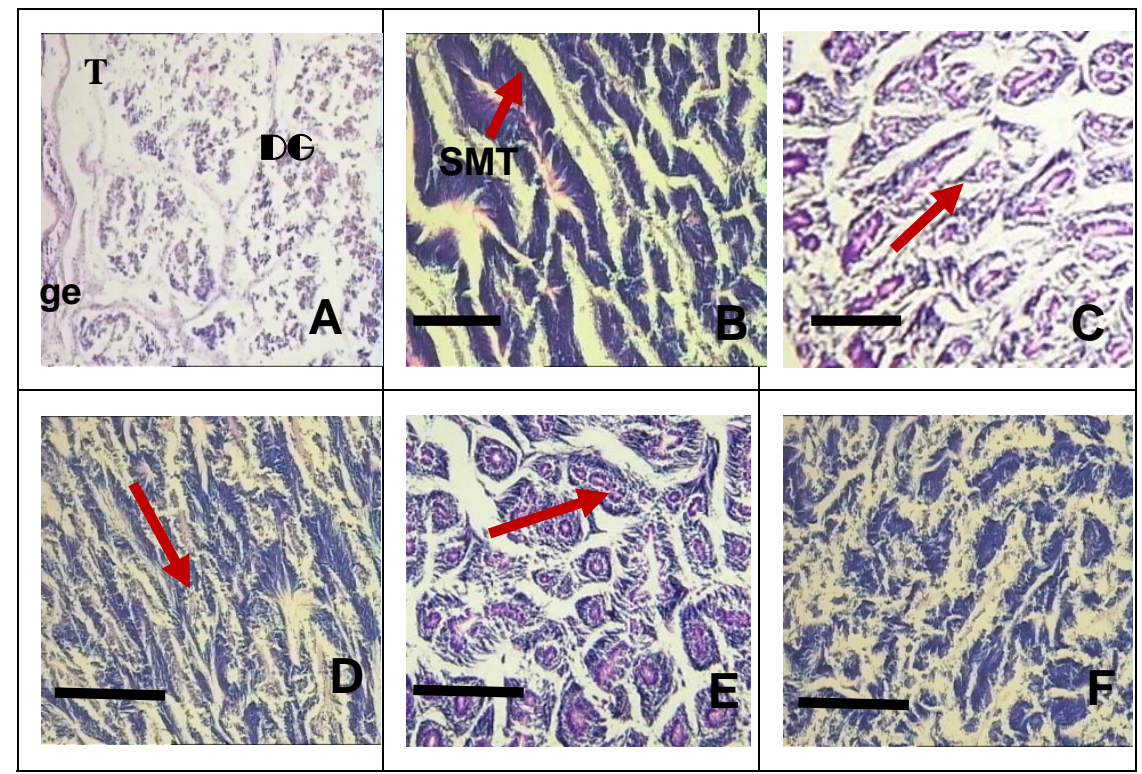

Figure 4. The histology of the maturity rate of H.asinina abalone's testis

(Bar scale: A: -; B, C: $5 \mu \mathrm{m}$; D, E, F: $10 \mu \mathrm{m}$ )

Notes:

A. Gonad was not yet developed (Immature); $\mathrm{T}=$ testis, $\mathrm{DG}=$ digestive gland, $\mathrm{ge}=$ germinal epithelium .

B. Gonad started to develop (Proliferated), SMT = spermatogonia.

C. Gonad was developed (Maturing). The arrow showed thin layer of spermatozoa (number of not-solidified spermatozoa).

D. Gonad was matured (Ripe). The arrow indicted the thick layer of spermatozoa.

E. Gonad was partially spawned. The arrow pointed to the cavities around the empty tubules (sperm pouch).

F. Gonad was totally spent. Testis was no longer carrying spermatozoa. 


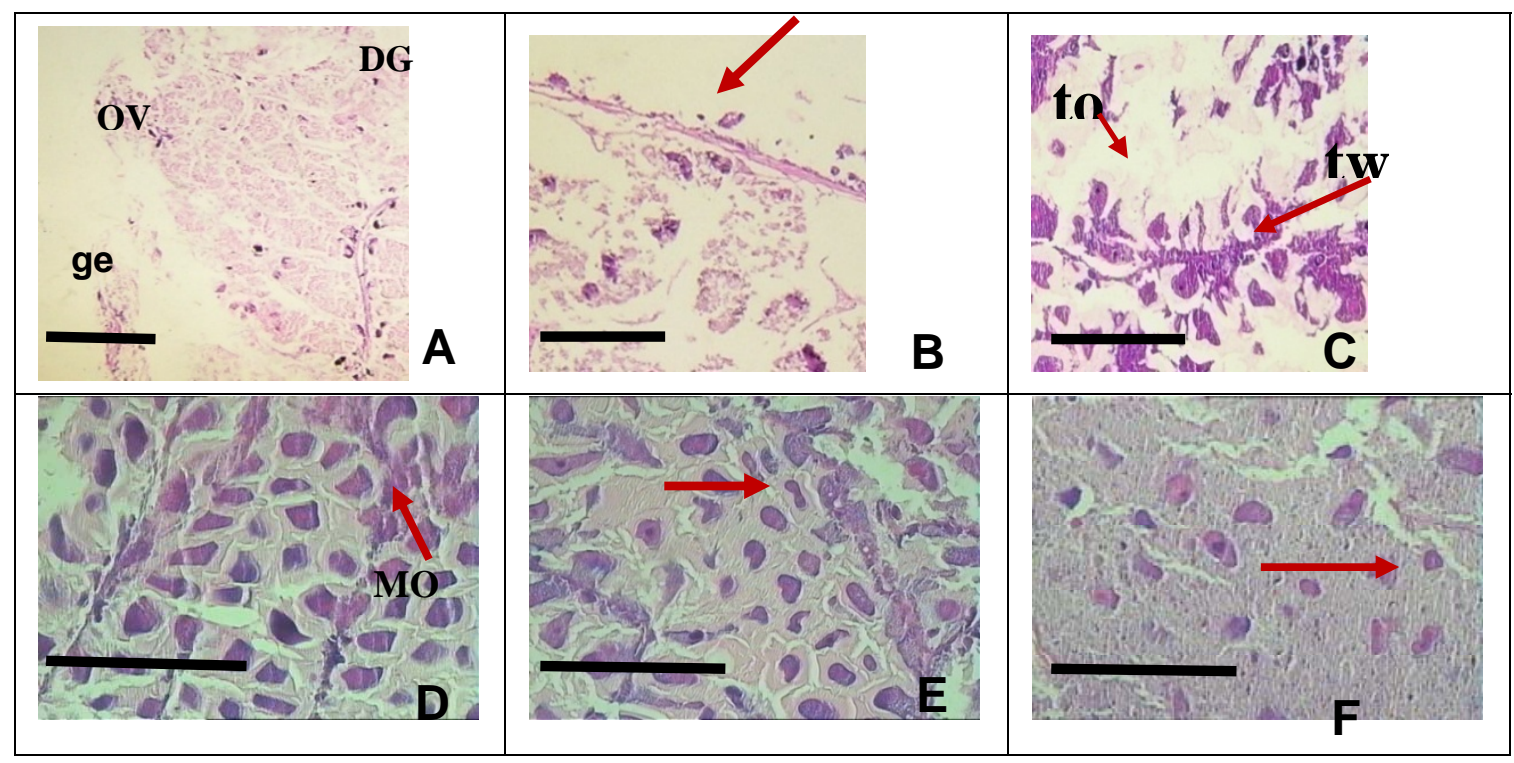

Figure 5. The histology photograph of the maturity rate of H.asinina abalone's ovary (Bar scale: A: $5 \mu \mathrm{m}$; B,C: $50 \mu \mathrm{m}$; D, E, F: $100 \mu \mathrm{m}$ ) Notes:
A. Gonad was not yet developed (Immature); $\mathrm{OV}=$ ovary, ge = germinal epithelium, $\mathrm{DG}=$ digestive gland.
B. Gonad started to develop (Proliferated). The arrow pointed to previtellogenic oocytes (not-yet developed oocytes).
C. Gonad was developed (Maturing). The arrow showed teardrop-shaped oocytes.
D. Gonad was matured (Ripe). Ovary was fully containing the ripe egg ( $\mathrm{MO}=$ matured oocytes).
E. Gonad was partially spawned. The arrow indicated the shrunk gonad membrane (gonad lumen).
F. Gonad was totally spent. Ovary was empty with only few oocytes were shrunk/destroyed.

\subsection{Gonad Maturity Rate}

The distribution of gonad maturity rate was shown in Figure 6 for male abalone and in Figure 7 for female abalone.

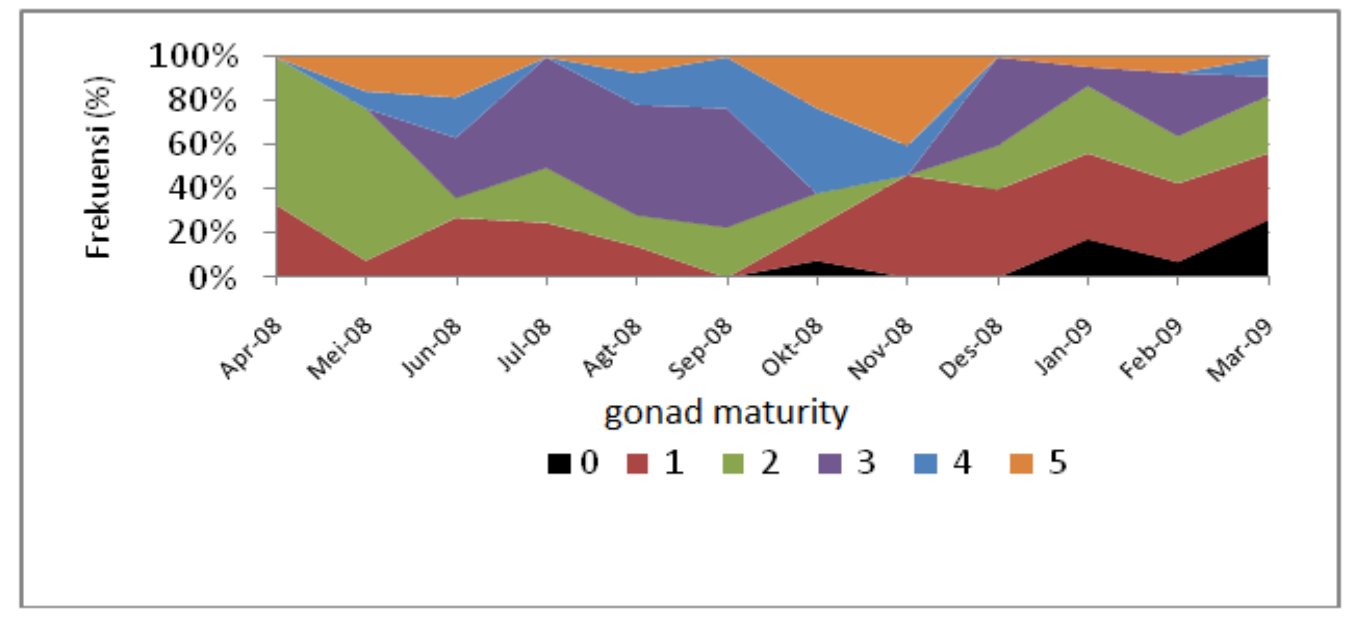

Figure 6. The distribution of gonad maturity rate of male abalone based on sampling period 


\section{Macrothink}

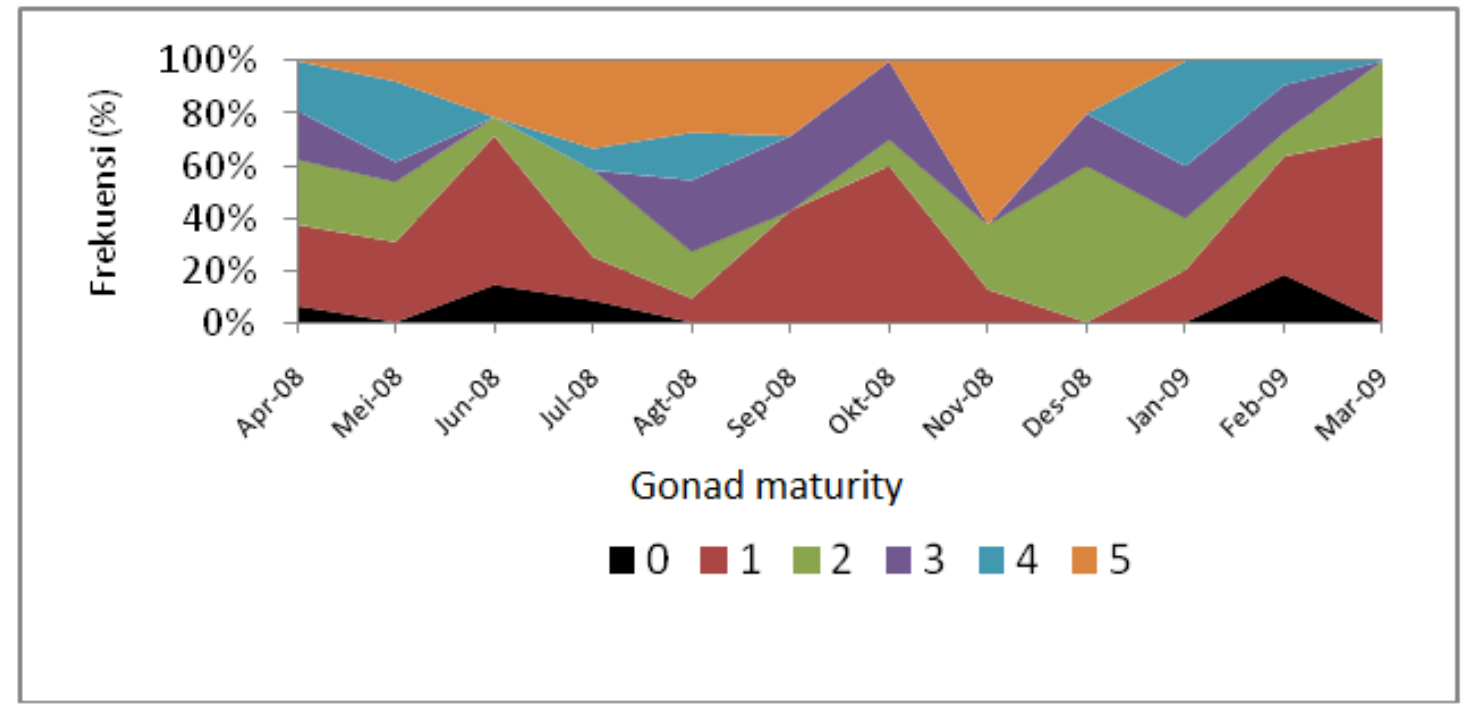

Figure 7. The distribution of gonad maturity rate of female abalone based on sampling period

Based on Figure 6 and Figure 7, Gonad Maturity Rate 3 was observed in male abalone in June-September 2008 and December 2008-March 2009, while it was figured out in female abalone in April-May 2008, August-October 2008, and December 2008-February 2009. These phenomena indicated that male abalone at research location could reach gonad maturity in two peak periods, while the female needed three peak periods.

Gonad Maturity Rate 4 for male abalone was discovered in May-June 2008, August-November 2008, and March 2009. In female abalone, it was found in April, May, July and August 2008 and January-February 2009. Male abalone at Gonad Maturity Rate 5 was found in May, June, August, October, November 2008 and January-February 2009. If male and female abalones should be compared, GMR 3 and GMR 4 were occurred simultaneously, meaning that the spawning of abalone was synchronous.

Abalone spawning peak occurred in July, in the beginning of dry season, when temperature increased, the spawning peak once again happened in October, and it was the beginning of rainy season. It was consistent to Nash (1992) who said that in Thailand, Philippine and Indonesia, $H$. asinina was spawning throughout year. In Heron Reef-Australia, $H$. asinina spawned only in the end of summer at the south hemisphere (Hart, et al, 2008).

In New Zealand, H. iris and H. australis spawned in the fall and spring seasons of south hemisphere (Hahn, 1989a). In Japan, $H$. discus spawned from October to November, while $H$. discus hannai spawned from July to October (Hahn, 1989a) 


\section{Macrothink}

\subsection{Gonad Maturity Index}

Gonad Maturity Index (GMI) of male and female abalones was shown in Figure 8. Male and female abalones had similar gonad index pattern, as shown by two peak periods, July 2008 and October 2008. It meant that in these two periods, GMI of male and female abalones was developed synergistic.

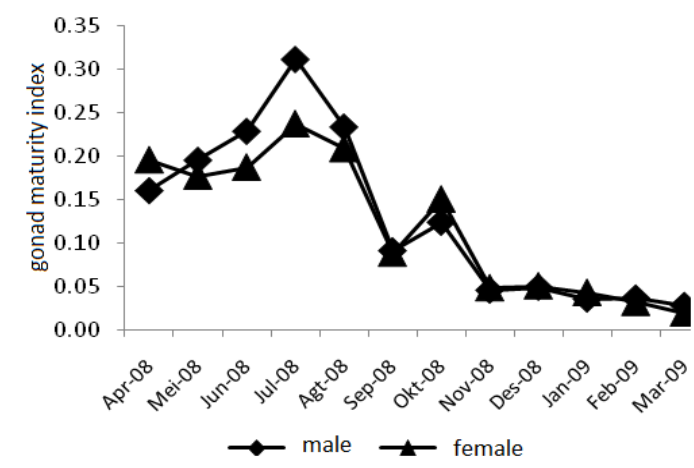

Figure 8 . The curve of gonad maturity index of male and female abalones during sampling

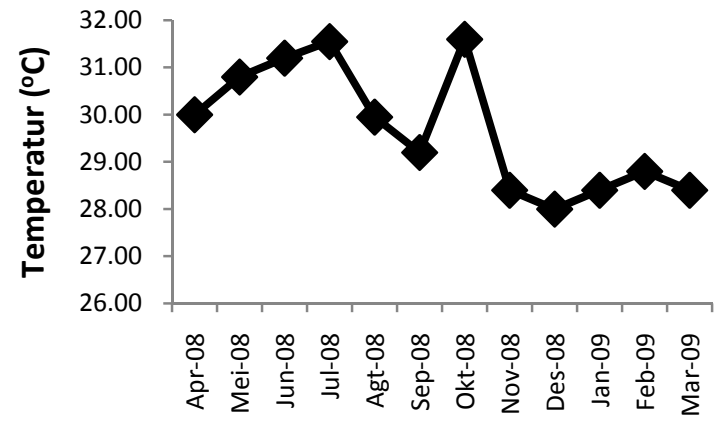

Figure 9. The average of sea temperature during sampling

Gonad index was dramatically increased since July, but drastically decreased in December. If Figure 8 and Figure 9 were compared, there was a similar curve pattern between the curve of abalone gonad index rate and the curve of sea temperature. It signified a close relationship between gonad development and sea temperature. Some previous authors admitted that the development of abalone gonad was correlated positively with the change of environmental factors such as temperature (Hahn, 1989b; Chen \& Chen, 2000), length of contact with the air during the ebb (Hahn, 1989b), the level of tide and ebb, and food or nutrient (Shepherd \& Steinberg, 1992; Bautista-Teruel et al., 2003). The number of spawning cycle days was decreased with the increased temperature (Moss, 1998).

Compared to GMI of tropical abalone at Tanakeke Islands, Fukazawa et al. (2007) found that H. discus hannai spawned few times, at least twice during a spawning cycle, while Tutshulte and Connell (1981) asserted that tropical abalone could spawn many times such that great energy for once spawning was not obviously needed because the egg was released in gradual fashion, few by few. In the less favorable condition, for instance, in the low temperature $\left(10-15^{0} \mathrm{C}\right)$, abalone could reabsorb the egg (Fukazawa et al., 2007). 


\subsection{Reproductive Potential}

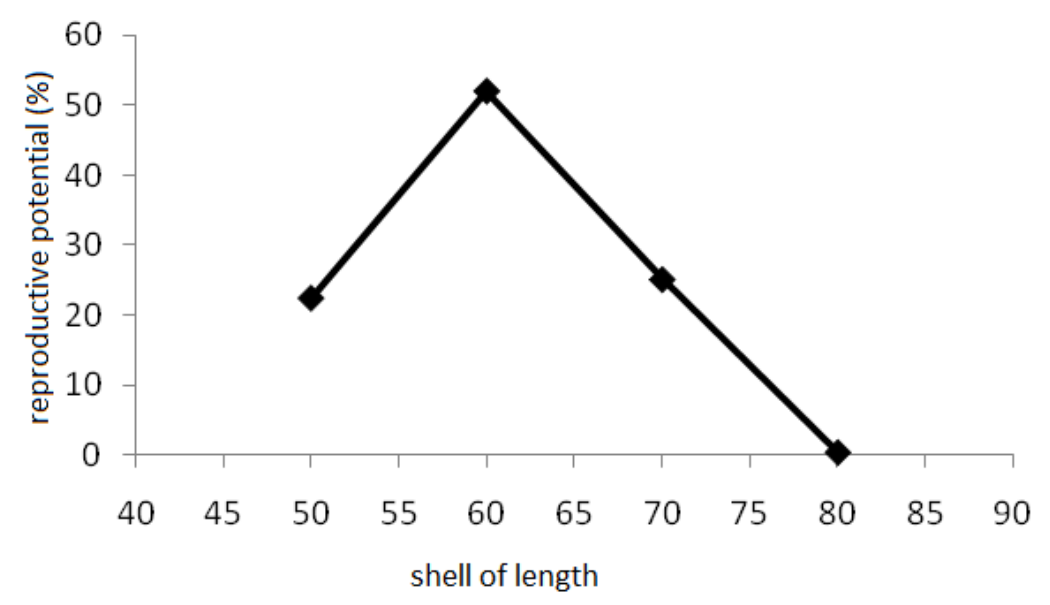

Figure 10. Reproductive potential of tropical abalone population of $H$. asinine

Figure 10 showed that abalone at shell length of $60-70 \mathrm{~mm}$ gave the greatest contribution to the reproductive potential of abalone population. It was consistent to the finding of the beginning of gonad maturity, which showed that the beginning of gonad maturity either for male or female abalones started at shell length of $64 \mathrm{~mm}$. Hahn (1989b), determined that abalone remained in the reproductive peak at shell length of $65-70 \mathrm{~mm}$.

\subsection{Fecundity}

Total fecundity rate was only observed in the gonad matured abalone, precisely at Gonad Matured Index (GMI) 3, 4, and 5. Based on the result of fecundity calculation, it was obtained that total fecundity rate of $H$. asinina tropical abalone in water of the Tanakeke Islands was various starting from 255.900 to 756.200 eggs with shell length of 53.5-77.0 mm.

Result of research by Nash (1992) on H. asinina tropical abalone in the laboratory condition indicated that the fecundity of this abalone ranged from 157.667 to 603.143 eggs with shell length of 58.1-69 mm. According to Omar and Litaay (2006), the fecundity of H. rubra abalone was in the range of $1.09-7.50$ millions eggs per female individual at shell length of $120-145 \mathrm{~mm}$. The fecundity of $H$. kamtschatkana abalone was 3 millions eggs per female individual at shell length of $125 \mathrm{~mm}$, but it was 11.3 millions eggs at shell length of $144 \mathrm{~mm}$ (McShane, 1992). The difference of abalone fecundity in different species was caused by the difference of shell length and body weight. The increase of shell length and body weight was always followed by the increased fecundity.

The result of regression analysis over the relationship between total fecundity and shell length was that the relationship was linear by the equation $\mathrm{F}=-74.894+18.821$, with correlation coefficient rate of 0.8729 (Figure 11A). The relationship between fecundity and gonad weight was found by equation $\mathrm{F}=92.697+53.103$, with correlation coefficient rate of 0.9187 (Figure 11B). The relationship between total fecundity and body weight of abalone 


\section{Macrothink}

Aquatic Science and Technology

ISSN 2168-9148 2013, Vol. 1, No. 2

was also linear by equation $\mathrm{F}=17.539+6.728$, with correlation coefficient rate of 0.8456 (Figure 11C). By these three equations, the relationship between fecundity and gonad weight was the strongest of others, such as the relationship between fecundity and body weight and/or the relationship between fecundity and shell length. This strength was reflected by the biggest correlation coefficient rate. Alternatively, it was easier to use morphology, such as body weight, to estimate total fecundity of abalone if it should be compared with body length.

A linear relationship between fecundity and body weight, and also between fecundity and gonad weight, indicated that the number of eggs in the ovary was increased proportionally with these weight variables. Some previous authors also obtained a linear relationship between fecundity and body weight Shepherd et al., (1995).

The number of fecundity was different with sampling period. Research showed that July was the most suitable timing for reproductive period of abalone at Tanakeke Islands, South Sulawesi. Total fecundity rate in the sampling period was shown in Figure 12.
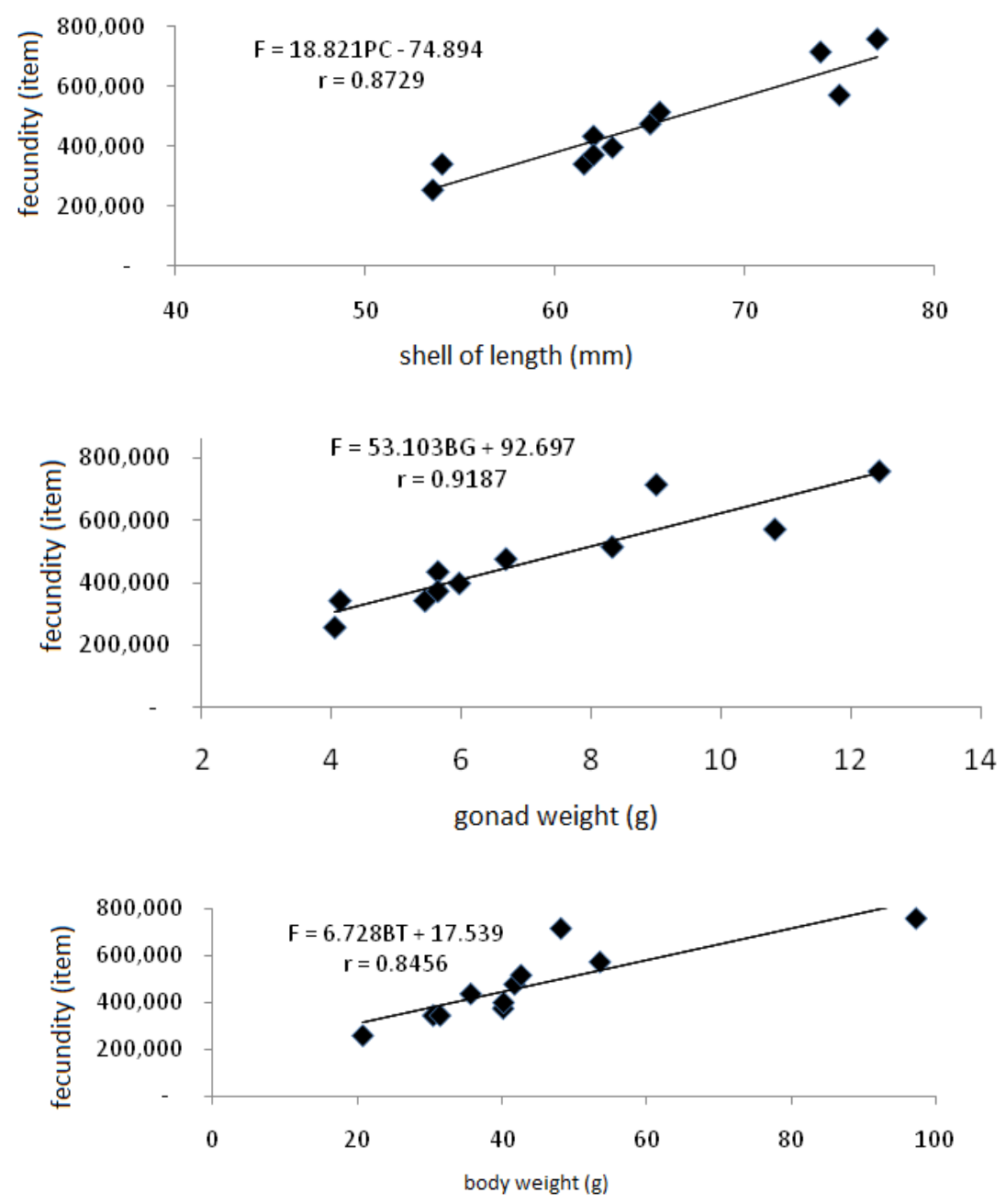

Figure 11. The curve of the fecundity of $H$. asinina tropical abalone

Notes: (A) The curve of the relationship between fecundity and shell length; (B) The curve of the relationship between fecundity and gonad weight; and (C) The curve of the relationship between fecundity and body weight. 


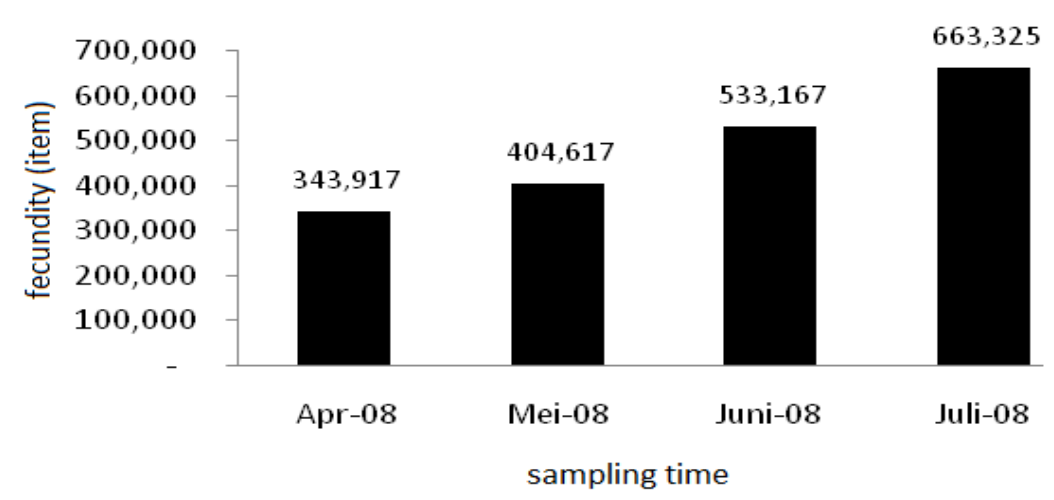

Figure 12. The histogram of the fecundity rate based on the sampling period of $H$. asinina abalone

The fecundity rate in July was influenced by one environmental factor, which was temperature. During this month, the season changed because it was the beginning of dry season where the temperature was usually increased (Figure 12). The increased temperature might influence reproductive strategy of abalone because the increased temperature was followed by food supply such that it stimulated abalone to lay the egg. Adult abalone then had appropriate timing for egg layering. Adult abalone could also release their gamete under specific environmental stimulation such as during storm or cyclone (Singhagraiwan \& Doi. 1992).

Fukazawa, (2007) asserted that egg quality of $H$. discuss hannae abalone, such as biochemical composition, might influence larvae and post-larvae periods. The number of lipid and protein inside the egg was influenced by temperature change, where the increase from high temperature was higher than that from low temperature. Fukazawa (2007) added that at optimum temperature that was suitable for abalone spawning, the egg was layered in the suitable waters $\left(20-25^{0} \mathrm{C}\right)$. If the waters were not suitable $\left(15^{0} \mathrm{C}\right)$, abalone reabsorbed their egg.

Hahn (1998b) reported that like most abalones, the gamete of H. discus hannai in the ovary developed into a cohort, and the egg was layered throughout a spawning season. Some abalone species had ability of layering eggs for several times (Effendy, 2007). These reports described oogenesis cycle during the egg layering season for tropical abalone where the egg developed every year except for April and May.

\section{Conclusion}

Result of research of $H$. asinina tropical abalone in the waters of Tanakeke Islands might conclude that:

1) Abalone that was chatched in Tanakeke Islands had potential of being local broodstock of South Sulawesi based on the length size and body weight.

2) The relationship between shell length and body weight of male and female tropical 
abalones was isometric when male and female was compared.

3) Male abalone reached the beginning of gonad maturity at shell length of $65.5 \mathrm{~mm}$, while female abalone attained it at $64.09 \mathrm{~mm}$.

4) Abalone spawned throughout year with two spawning peaks, precisely at the beginning of dry season and of rainy season. Therefore, the broodstock was available throughout the year.

5) Fecundity increased proportionally with the increase of length and body weight.

\section{References}

Bardos, D. C., Day, R. W., Lawson, N. T., \& Linacre, N. A. (2006)). Dynamical response to fishing varies with compensatory mechanism: An abalone population model. Ecological Modelling, 192, 523-542. http://dx.doi.org/10.1016/j.ecolmodel.2005.07.015

Bautista-Teruel, M. N., Fermin, A. C., \& Koshio, S. S. (2003). Diet development and evaluation for juvenile abalone, Haliotis asinina: animal and plant protein sources. Aquaculture, 219, 645-653. http://dx.doi.org/10.1016/S0044-8486(02)00410-6

Campbell, A., Lessard, J., \& Jamieson, G. S. (2003). Fecundity and seasonal reproduction of northern abalone, Haliotis kamtschatkana, In Barkley Sound, Canada. Journal of Shellfish Research, 22(3), 811-818.

Capinpin, Jr. E. C., Encena II, V. C., \& Bayona, N. C. (1998). Studies on reproductive biology of the Donkey's ear abalone, Haliotis asinina Linne. Aquaculture, 166, 141-150. http://dx.doi.org/10.1016/S0044-8486(98)00275-0

Chen, Y. C. (2007). Immobilization of twelfe benthic diatom species for long-term storage and as feed for post-larval abalone Haliotis diversicolor. Aquaculture, 263, 97-106. http://dx.doi.org/10.1016/j.aquaculture.2006.12.008

Del Proo, S. A. G. (1992). A review of the biology of abalone and its fishery in Mexico. In Shepherd, S. A., M. J. Tegner \& S. A. Guzman del Proo (Eds.), Abalone of The World, Biology, Fisheries and Culture (pp. 341-360). Oxford: Blackwells.

Effendy, I. J. (2007). Pengembangan teknologi pembenihan dan budidaya abalon (Haliotis asinina) di Indonesia, pp. 1-3. Seminar Nasional Molluska. Universitas Diponegoro. Semarang.

Fleming, A. E., \& Hone, P. W. (1996). Abalone aquaculture: an introduction. Aquaculture 140, 1-4. http://dx.doi.org/10.1016/0044-8486(95)01183-8

Fukazawa, H., Kawamura, T., Takami, H., \& Watanabe, Y. (2007). Oogenesis and relevant changes in egg quality of abalone $H$. discus hannai during a single spawning season. Aquaculture, 270, 265-275. http://dx.doi.org/10.1016/j.aquaculture.2007.03.015

Gulland, J. A. (1977). Fish population dynamics. London: John Wiley and Sons.

Hahn, K. O. (1989a). Gonad reproductive cycles. In Hahn, K. O. (Ed.), Handbook of Culture of Abalone and Other Marine Gastropods (pp 13-39). Boca Raton, Florida: CRC Press, Inc. 


\section{Macrothink

Hahn, K. O. (1989b). Nutrition and growth of abalone. In Hahn, K. O. (Ed.), Handbook of culture of abalone and other marine gastropods ( $\mathrm{pp}$ 135-156). Boca Raton, Florida: CRC Press, Inc.

Hart, A. M., Fabris, F. P., Brown, J., \& Murphy, D. (2008). Digital video surveys of abalone (Haliotis sp.) stocks by commercial fishers in Western Australia. Fisheries Research, 93, 305-314. http://dx.doi.org/10.1016/j.fishres.2008.06.002

Maliao, R. J., Webb, E. L., \& Jensen, K. R. (2004). A survey of stock of the donkey's ear abalone, Haliotis asinina L. in the Sagay Marine Reserve, Philippines: evaluating the effectiveness of marine protected area enforcement. Fisheries Research, 66, 343-353. http://dx.doi.org/10.1016/S0165-7836(03)00181-4

McShane, P. E. (1992). Early life history of abalone: a review. In Shepherd, S. A., M. J. Tegner \& S. A. Guzman del Proo (Eds.), Abalone of the Word: Biology, Fisheries and Culture (pp. 120-138). Fisheries Research Division. Ministry of Agriculture and Fisheries. Wellington, New Zealand Oxford: Blackwells.

Nash, W. J. (1992). A evaluation of egg-per-recruit analysis as a means of assessing size limits for blacklip abalone (Haliotis rubra) in Tasmania. In Shepherd, S. A., M. J. Tegner \& S. A. Guzman del Proo (Eds.), Abalone of the Word: Biology, Fisheries and Culture (p. 334). Oxford: Blackwells.

Omar, S., Bin, A., Litaay, M., \& Anwar, N. (2006). The occurrence of tropical abalone (Haliotis spp.) at reef flat of onetambu Island, Makassar. Jurnal Torani, 16(2), 142-147.

Rounsefell, G. A. ((1975). Ecology, utilization, and management of marine fisheries. The CV Mosby Company, London.

Setyono, D. E. D. (2009). Abalon, biologi dan reproduksi. LIPI Press. 92 hal.

Shepherd, S. A., \& Steinberg, P. D. (1992). Food preferences of three Australian abalone species with a review of the algal food of abalone. In Shepherd, S. A., M. J. Tegner \& S. A. Guzman del Proo (Eds.), Abalone of The World, Biology, Fisheries and Culture (pp. 169-181). Oxford: Blackwells.

Singhagraiwan, T., \& Doi, M. (1992). Spawning pattern and fecundity of the Donkey's ear abalone, Haliotis asinina Linne observed in capity. Thai Mar. Fish. Res. Bull. 3, 61-69.

Yunus, M. (2009). Strategi pengelolaan ekowisata kepulauan tanakeke Kabupaten Takalar. Tesis. Program Pascasarjana, Universitas Hasanuddin, Makassar.

\section{Copyright Disclaimer}

Copyright reserved by the author(s).

This article is an open-access article distributed under the terms and conditions of the Creative Commons Attribution license (http://creativecommons.org/licenses/by/3.0/). 